\title{
From Foot-Slogging to Call Centres and Direct Mail: A Framework for Analysing the Development of District-Level Campaigning
}

\author{
Justin Fisher (Brunel University) \& David Denver (Lancaster University)
}

\begin{abstract}
Drawing upon ideas formulated with national level campaigning in mind and also analyses of district or local-level campaigning, a conceptual framework to assist in analysing the development of district-level campaigning is presented. The proposed framework is further amplified, explained and tested using quantitative and qualitative data collected at British general elections between 1992 and 2005. Various aspects of district (constituency) campaigning in Britain are examined and the extent of change over four general elections analysed. In broad terms, the data show a good fit with the framework which offers a useful way of thinking about developments in campaigning both within and across countries.
\end{abstract}

\section{Introduction}

For most political parties election campaigning is a core activity. Apart from a few on the fringes of politics, all parties contest elections and seek to win support among the electorate. For as long as there have been competitive elections, indeed, there has been election campaigning. Parties devote enormous resources to the activity, national campaigns attract intense media interest and many thousands of party activists (still) get involved at local level. Not surprisingly, this key area of party activity has attracted considerable attention from scholars. For the most part they have focused on national-level campaigning but in recent years there has been a resurgence of interest in 'on-the-ground' campaigning at the level of the electoral district - both in Britain and elsewhere. This literature has thrown light on a number of important questions including how campaigning has changed, in style and in activities undertaken, in response to changes among the electorate and to technological developments. In addition, studies have explored differences between parties in the extent to which they are able to harness their campaign resources effectively. Such differences often reflect cultural and institutional features of parties. The respective roles assigned to the central bureaucracy and grass-roots activists in the management of campaigns is an aspect of campaign organisation that has implications for perennial questions relating to the distribution of power within parties. Academic interest in election campaigning has been sustained by the emergence of a burgeoning literature on political communications and 
political marketing in which a particular area of interest has been the extent to which parties are increasingly using campaign techniques derived from the commercial world.

Attempts have been made to provide a comparative framework for understanding the development of campaigning at national level but there has been little comparable work on district-level campaigning, despite the emerging evidence that in a number of countries such campaigning can significantly affect election outcomes. This article represents an attempt to address this lacuna. In the first section we discuss two models of change in national campaigning before going on to draw some lessons from comparative studies of local campaigning.

\section{The Development of National Campaigning}

In her comparative analysis of campaigning, Pippa Norris (2002) suggests that campaigns have developed through three phases: Pre-modern (characterising the period from the midnineteenth century to the 1950s), Modern (from the early 1960s to the late 1980s), and Postmodern (from the 1990s onwards). Pre-modern campaigning was pre-eminently local and focused on direct contact between candidates and citizens. Campaigns were locally organised, locally staffed and based on traditional labour-intensive methods. Such national campaigning as existed was co-ordinated by party leaders and was characterised by shortterm, ad hoc planning. Modern campaigns involved greater co-ordination by central party officials. The national campaign was clearly paramount (reflecting the growth of television) and party campaign activity became more professionalised. Finally, the Post-Modern campaign involves continuous campaigning - it is no longer confined to the few months before an election - and much use of professional consultants. Media management is a key (perhaps the key) activity at national level and although more emphasis is given to local campaigning (involving new techniques) local activity becomes more tightly managed and co-ordinated by the centre.

A categorisation of this kind is inevitably somewhat simplified. It seems far-fetched, for example, to claim that nineteenth century campaigns belong in the same ('pre-modern') category as those in the 1950s. Arguably, national campaigning began to emerge at the end of the nineteenth century, developed between the wars and was already well-established by 
the 1950s (see Denver and Hands, 1997: 3-18). Nonetheless, Norris's typology is interesting and suggestive.

Farrell and Webb (2002) have also developed a useful three-stage comparative model of campaign professionalisation which echoes some of the work of Norris. They argue that the development of campaigning is a function of technical, resource and thematic changes. Technical developments refer principally to the growth of television and, more recently, new communication technologies which include the use of direct communication with voters and the internet. Such developments are accompanied by increased attention to campaign preparation. Resource developments refer to the growing strength and influence within the party of the central bureaucracy, the professionalisation of party staff, the use of outside professional advisors and of an increasing range of feedback mechanisms such as polls and focus groups. Finally, thematic changes refer to the process of 'presidentialisation', the argument being that, making use of new forms of communication, campaigns have focussed increasingly on party leaders,. According to Farrell and Webb (2002: 122) this reflects a shift from 'selling to marketing', which manifests itself in increasingly sophisticated targeting of key voters and a move away from party 'propaganda' towards campaign communications conceived of as marketing tools.

Although Norris's approach refers to the balance between national and local campaigning, her focus is primarily on the national campaign and the same is true of Farrell and Webb. Neither provides (or is concerned to provide) a comprehensive typology for the study of district-level campaigning alone. There are some areas of obvious overlap between national and district campaigns - indeed, we have suggested elsewhere that the two are becoming increasingly integrated - but a number of aspects of national campaigning, such as television and media management, for example, are relevant only at that level.

\section{District-level Campaigning}

Focussing explicitly on constituency (district) level campaigning, Denver and Hands (2002) have suggested a framework which they described as Fordist and Post-Fordist forms of campaigning. Fordism refers to 'mass production' in district campaigns - essentially individual district campaigns are undifferentiated, require few specialized skills and are mainly concerned with the mobilisation of supporters. Post-Fordism involves flexible 
specialization and niche marketing. Thus, campaigns and campaign techniques are adjusted to meet voter demands, and this requires more flexible and more skilled campaign managers.

Denver and Hands note that the application of the Fordist/Post-Fordist distinction to district campaigning is exploratory only and concede that it meets with mixed success. While many of the new campaign techniques have Post-Fordist connotations, the same cannot be said of developments in the organisation and management of campaigns. A fuller categorisation is required, therefore, that captures more of the dimensions of campaign change.

The need for an alternative framework is further highlighted by comparative work, which suggests that developments in district-level campaigning vary across different countries. In Canada, for example, Carty et al. (2003) posit a two-stage process that explains how campaigns vary in terms of style, funding and local autonomy. The competitiveness of the electoral district, the nature of the nomination process and the structure of the party combine to produce four main candidate types. Each of these types in turn is associated with a distinctive pattern of campaign organisation and practice. Variations in the extent of local autonomy indicate that campaigns have evolved from being purely local affairs and now involve the central or regional party to a greater or lesser degree.

In New Zealand, Denemark (2003) argues that moves towards Norris' Modern phase were delayed. Indeed, it was not until the late 1970s that television began to play a key role in campaigns. Until the late 1980s local campaigns were 'low profile, non-professional, nationally focussed, and susceptible to local MP demands for attention, irrespective of the seat's overall strategic importance' (p. 603). In reaction to poor election results, however, the major parties began to rethink campaigning and the change to the electoral system in 1996 accelerated the process of change. As a consequence, district campaigning was modernised in much the same way as in other countries. Ward's (2003) study of campaigning in Australia suggests a similar pattern of change. From the 1980s, there was a big shift in Australian district campaigning with an increasing emphasis on tactical seats and key voters within them. In Ireland, however, the Norris model fits poorly. According to Marsh (2004) local campaigning in Ireland remains very much a matter of personal contact between candidates and voters - 'meeting the folks' (p. 263). Irish district campaigns are essentially pre-modern. In the 2002 Irish elections, for example, some 55\% of voters recalled being visited by at least one candidate - in both absolute and comparative terms, a very high figure 
(pp. 249-50). In addition, everyone involved - candidates, party professionals, commentators - believes that personalised campaigning is effective (and this is supported by statistical analysis) so that that Irish campaigning is likely to remain pre-modern for the foreseeable future.

\section{A Framework for Analysing Change in District Campaigning}

Overall, then, previous work on district campaigning suggests that it would be useful to develop a framework that moves beyond simplified notions of 'traditional' and 'modern' styles of campaigning and identifies different stages of development as well as core themes. In particular, it would allow us to evaluate the extent to which parties' campaign styles develop and enable us to compare campaigning by different parties, as well as campaigns in different countries. We seek to introduce such a framework here and then test it using available data from detailed studies of campaigns at the last four general elections in Britain (1992, 1997, 2001 and 2005).

The intention is that the framework can be used for comparative purposes. It is apparent, however, that differing institutional contexts such as the electoral system, campaign regulations, the party system and so on will have a significant impact on some of its aspects (see Norris, 2002). For example, the targeting of marginal constituencies is likely to be a much more significant activity in plurality and majoritarian electoral systems than in (at least some) PR systems. The structure of the party system will also be important: in multi-party systems there are likely to be greater variations in campaigning than in two- or three-party systems. Finally, variations in electoral regulation will have a mediating impact on campaigning. Where campaign expenditure limits exist, for example, those set at a lower level are likely to promote more labour-intensive volunteer-led forms of campaigning. An example of institutional mediation leading to campaign variation can be found in Farrell and Scully's study of MEPs (2007). They show that voter canvassing using either personal contact or by telephone, is more prevalent in candidate-focussed systems like STV and in Britain, where despite the introduction of List PR for European Elections, a culture of more traditional campaigning evidently endures (Farrell \& Scully, 2007: 130-7).

Norris's 'dominant era' model is not entirely suitable as a framework - it is mainly concerned with national campaigning and does not fit particularly well in some countries. Our typology is derived, therefore, from Farrell and Webb's model of campaign professionalism which 
allows for more nuanced and accurate indicators of campaign change but is adapted here to refer specifically to district-level campaigning. The framework is summarised in Figure 1. We propose a three-stage model, each stage being differentiated by Technical, Resource and Thematic developments. Technical matters refer principally to two things. First, the extent to which district campaigns involve long-term preparation both in the district and at party headquarters. Second, the extent to which parties utilize technology as a campaign tool and the balance between the use of technology and more traditional campaign techniques. Resource changes focus on three aspects of campaigning. Firstly, there is the degree of central party control and influence over district campaigns and, secondly, the degree to which the staffing of local campaigns has moved from a voluntary basis towards becoming more professionalised. Thirdly, this aspect also includes feedback techniques - how district-level (and national) parties monitor levels of support within the various electoral districts. Finally, the thematic category relates to two aspects of campaigning - the involvement of leading politicians in district campaigns (mainly through personal visits) and the extent to which local campaigns have evolved from being primarily concerned to mobilise specific social categories of electors towards the kind of marketing that Farrell and Webb describe, which involves targeting specific individual voters.

\section{[Figure 1 About Here]}

In what follows we illustrate the use of this framework in the British context, largely on the basis of surveys of election agents (who are responsible for running local campaigns) at each of the four general elections from 1992 to 2005, but also using qualitative information collected from party officials over the same four elections. The surveys were conducted immediately after each general election and the population covered included all agents of the three main parties in Britain (Conservative, Labour and Liberal Democrat) which are the objects of our attention here. With one exception, there were representative responses for all parties in each election (response rates are detailed in the Appendix). The exception is the case of the Conservatives in 2005 so that results based on these responses should be treated with caution ${ }^{1}$. Where appropriate, we have drawn attention to this in the text. Finally, while

1 The response from Conservative agents in the 2005 survey was disappointing, particular since responses from them in previous studies had been on a par with other parties. The likely reason for the lower response rate was poor address data provided for Conservative agents. Nonetheless, whilst the response rate is low for this group in this election, the data generated are nevertheless indicative and 
districts is the appropriate comparative term for the electoral units under consideration here, we generally use constituencies in what follows as that is the name for the relevant British electoral districts.

\section{Applying the Comparative Framework to the British Case}

\section{Technical Changes}

\section{Campaign Preparation}

In previous work (Denver et al., 2003), we have shown on the basis of qualitative data how the parties at national level have increasingly planned and prepared their constituency campaigns in advance. In preparation for the 1992 election, for example, Labour set up a key seats unit some two years before polling day and such advance planning and organisation is now routine in all parties. We consider here, however, whether there is evidence of a move towards longer-term campaign preparation in the constituencies themselves. Our surveys of election agents contained a number of questions relating to campaign preparations and in order to get an overall picture, we have created two indices of long-term preparation. The first covers elections from 1992 to 2005 and the second those from 1997 onwards since additional questions were asked in later surveys. The variables used to construct the indices are shown in the Appendix. The datasets relating to each individual election were pooled and relevant variables entered into Principal Components Analyses. In each case, these produced single components with associated factor scores and we take these factor scores as overall measures of the extent of long-term preparation at local level. As in previous analyses (see, for example Denver and Hands 1997; Fisher, Denver and Hands, 2006a), the factor scores have been standardized around a mean of 100 to allow for ease of interpretation, both between parties and over time.

Table 1 shows the mean scores on the long-term constituency preparation indices for each party in each election. For this and subsequent tables, where appropriate, we have used

therefore useful. We take this view for the following reasons. First, we have indicated in each case, where the Conservative figure for 2005 should be treated with some caution. Secondly, whilst the response rate is lower than usual, it is not insignificant. Thirdly, where the data have been included in the calculation of more general indexes, they do not have the effect of making these indexes inaccurate - after checking, we find any effect to be marginal or non-existent. For these reasons, we are confident that the inclusion of the 2005 data for the Conservatives is justified, not least since to exclude the data would also mean the non-inclusion of the robust data from other parties. Moreover, our view is that weighting the data would introduce inaccuracies which would be more serious than any potential shortcomings with the existing data for 2005. 
analysis of variance (an F test) to test for the significance of differences between means. On the face of it, there are few clear trends. Only the Conservatives appear to demonstrate the anticipated pattern, increasing their mean level of campaign preparation at each election from 1997 onwards according to both indices. In both cases the 2005 figure is significantly different from the others, Labour campaigns, in contrast, appear to have engaged in progressively less long-term preparation since 1997 and indeed, using either index, the figure for 1997 is significantly larger than those for 2001 and 2005. There is no apparent trend for Liberal Democrat campaigns, although the figure for 1992 is significantly larger than the others and the dip in 2001 is significant when compared with 1997 and 2005 (on the basis of the second index).

When we disaggregate the scores for major parties according to the target status of constituencies, however, some important patterns emerge (Table 2). In this and subsequent tables, there are three categories of seat: Target Seats (which may include both seats being defended and seats held by another party); seats held by the party but not targeted (Held Not Target); and seats neither held by the party nor targeted (Not Held Not Target). As Denver and Hands (2002:111-2) point out, parties have always had target seats, but in practical terms this often meant little. In the 1990s, however, targeting became progressively more rigorous and far-reaching - a trend also apparent in other democracies (see, for example, Ward, 2003) - though not in all (see Carty et al., 2003). Under the simple plurality electoral system it is rational for parties to try, as far as possible, to concentrate campaign resources on target seats - those that they may gain or are in danger of losing - although there will inevitably be constraints on their ability to do this. For one thing, party membership may well be larger in seats where they have already been electorally successful (see Fisher, 2000; Fisher, Denver and Hands, 2006b). This means that not only members but the general resources that arise from larger memberships are likely to be in greater supply in seats that parties already hold.

Table 2 shows, first, that in almost all cases the extent of long-term planning is greater in target seats than in others. This is most pronounced for Labour whose target seats are significantly different in statistical terms from the other categories in all four elections. For the Liberal Democrats, given their small number of safe seats, the significant difference is likely to be between non-held non-target and other seats, and indeed, this is the case in 2001 and 2005. For the Conservatives, however, the only statistically significant differences are between non-held non-target seats and other seats in 1992, 1997 and 2001. Secondly, for all 
three parties long-term planning has declined in seats that were poor electoral prospects. ${ }^{2}$ The Conservatives have increased their level of long-term preparation election-on-election in target seats. This is as would be expected given the growing concentration on targets but long term-planning also appears to have increased in safe seats (held not targeted). This reflects a persistent problem for Conservative campaign managers in that their campaigns are often strongest in their safest seats, or at least nearly as strong as in their targets (Denver et al., 2003). Indeed, there is no statistically significant difference between targets and seats already held. There was little change in the extent of long-term planning in Liberal Democrat targets between 1997 and 2001 but a clear increase in 2005. There was also an increase in the seats held but not targeted. This is because almost all the Liberal Democrat held seats were originally won through targeted intensive campaigning and, even although some have become relatively safe, campaigns in them continue to be relatively strong. For Labour the results over time are more mixed. As already noted, long-term preparations are most extensive in target seats but one measure there was a decline in the level of advance preparations in targets in 2001 and again in 2005. On the second measure the dip in 2001 was reversed to an extent in 2005. The lower figures for both elections are probably explained by a decline in the number of party members involved in Labour campaigns (see Table 3).

\section{[Table 1 About Here]}

\section{[Table 2 About Here]}

Overall, the evidence relating to the development of long-term campaign preparation is somewhat mixed. There seems to be no trend in the overall scores but for all parties there is a fairly clear and generally increasing differentiation between different types of seats. By and large, 'hopeless' seats are falling behind in their levels of preparation compared with safe and target seats and, generally speaking, target seats are more prepared than safe ones. Thus, using this measure together with qualitative accounts of party preparations (see, for example, Denver et al., 2003, Fisher et al., 2007), we can say that in terms of long-term preparation the major parties have certainly moved to stage 2 in our analytical framework.

\footnotetext{
The Conservative 2005 figure is particularly unreliable here, being based on only six cases.
} 


\section{Traditional and Modern Campaign Techniques}

Party members are the bedrock of traditional constituency campaigning. They provide labour for a variety of tasks: doorstep canvassing, delivering leaflets, taking numbers at polling stations, 'knocking-up' voters on polling day and so on. Without party members it would be almost impossible to run a traditional constituency campaign focused on identifying supporters and mobilising them on polling day. Indeed, while Fisher, Denver and Hands (2006a) argue that simply having a large number of members is no guarantee of an effective campaign (compare Whiteley and Seyd, 2003), they concede, nonetheless, that a campaign involving relatively few members is likely to be less successful than one which can call upon a large volunteer work force.

During the period 1992-2005, however, there were significant changes in the average membership of constituency parties (Table 3). Compared with 1992 the membership of the two largest parties (Conservative and Labour) has declined significantly. For the Conservatives the picture has been one of almost continuous decline (the 2005 figures, for reasons previously explained, are possibly less robust). Labour membership increased in 1997 but has been declining since then, with the mean membership per constituency in 2005 being nearly 100 smaller than it was in 1992. Liberal Democrat membership also declined after 1992 but rallied somewhat in 2005 .

\section{[Table 3 About Here]}

Whatever the reasons for this decline in party membership, which is not unique to the United Kingdom (see Scarrow, 2002: 86-94), it is clear that British parties will have found it increasingly difficult to mount strong traditional campaigns from the 1990s. A second contextual point, which should be made in relation to changes in campaigning during this period is that there has been a rapid growth in the availability of (and decline in the cost of) technology such as computers, which can be used in election campaigning to reduce dependence on volunteer workers. The 1992 general election was dubbed 'the fax election' by Denver and Hands (1997) but by 2005 the fax had become all but obsolete and the use of personal computers in campaigning had become widespread.

So, the pool of labour available to work in traditional campaigns has by and large declined while a range of technologies that can be used to assist campaigns has become much more 
freely available. As comparative evidence shows, faced with a decline in membership parties often have little choice but to turn to more modern campaign tools in order, in part, to meet the shortfall of campaign workers (Ward, 2003; Denemark, 2003). To what extent, then, have campaigning techniques changed?

In previous work (Denver et al., 2003), we have described in general terms how parties have modernised their campaigns. Ward (2003) and Denemark (2003) have illustrated similar patterns in Australia and New Zealand respectively. We analyse these changes in more detail here by using indices which measure the extent of traditionalism and modernisation in local campaigns. The indices are based the variables shown in the Appendix and were calculated in the same way as those used to measure long-term campaigning. The traditionalism index includes measures of poster and leaflet distribution, doorstep canvassing, public meetings and what might be called 'manual' polling day activity - such as number taking and knocking up. As far as modernisation is concerned, not all the relevant questions were asked at each election (indeed, changing questions themselves reflect the modernisation of campaigns) and so we have calculated two indices. The first (Modernisation A) includes variables available in all four surveys; the second (Modernisation B) covers the elections of 1997, 2001 and 2005 and includes variables relating to the use of direct mail, telephone 'knocking-up' and a more accurate measure of the extent of telephone canvassing.

Table 4 describes the trends in traditional campaigning, as measured by mean scores on the relevant index. Overall, it shows that, despite a slight revival in 2005, traditional campaigning has tended to decline and the overall means for each year are statistically significantly different from one another. There are some variations by party, however. In the case of Labour in successive elections after 1992 there was less strong traditional campaigning and this decline is statistically significant. Traditional campaigning by the Conservatives and the Liberal Democrats also declined (significantly) until 2001. In 2005, however, the decline was reversed in both parties and scores on the traditionalism index were not significantly different from the 1992 scores. In the case of the Conservatives, this apparent reversal should be treated with some caution given the relatively small number of cases involved. In the case of the Liberal Democrats, however, there are no such concerns. The most likely explanation for any upswing in traditional campaigning by the Conservatives and Liberal Democrat in 2005 is the electoral context. All elections are not alike, and the context is likely to affect levels of activity (see for example, Denver et al., 2002). The 2005 contest was perceived as being far 
tighter than that of 2001, and in addition, it was thought that the Liberal Democrats had a real opportunity to make a significant electoral advance. Thus, just as Liberal Democrat membership grew, so traditional activities undertaken by members, also increased. The Conservatives too had some cause for optimism - certainly much more than in the previous two elections. So while the Conservative figure may be an exaggeration, the likelihood is that there was indeed an increase in traditional activity by these two parties. A large membership does not equate fully with intense activity (Fisher, Denver and Hands, 2006a) but the evidence presented here suggests that the intensity of volunteer activity in campaigns is fairly closely linked with the level of membership.

\section{[Table 4 About Here]}

In Table 5, we show trends in campaign modernisation on the basis of the two indices described above and the overall trends are clear enough. Whichever index is used there is an election-on-election increase in the modernisation of campaigns. In both cases the overall scores for each election are significantly different from one another. There is also a steady increase for each of the parties and in each case the differences between the earlier and later elections are statistically significant. What is also noteworthy is that the increase in Labour modernisation was far slower after 1997 than it was for the other parties. Labour appears to have made great strides after 1992, but has effectively consolidated its position thereafter. Notwithstanding our concerns about the Conservative data for 2005, it appears that increases in Conservative and Liberal Democrat modernisation have been steadier, with the Liberal Democrats rapidly 'catching-up' with the two big parties.

\section{[Table 5 About Here]}

By and large then, traditional campaigning has been declining, whilst modernisation has been increasing. We can establish the relative balance between traditionalism and modernisation by subtracting the index of modernisation from the index of traditionalism to produce a 'net' score. Since both are measured on the same scale (having been standardised around a mean of 100), the results are easy to interpret. Positive net scores suggest more traditionalism relative to modernisation while negative scores suggest the reverse and the distance of net scores from zero allows us to establish any trends in this balance. Table 6 shows the mean net scores for each party as well as the overall score at each election and the trends are again relatively clear - each election sees the balance of campaigning tilting more towards modernisation, 
with 2001 being the 'tipping point'. With only one exception, all scores are positive until 1997 and all are negative thereafter. For the first modernisation index the 2001 and 2005 overall scores are significantly different from those for 1992 and 1997; for the second, all three scores are significantly different from one another. The net scores for the individual parties suggest a trend towards modernisation and in almost all cases the scores for the later elections are significantly different from those for the earlier elections, in the expected direction.

\section{[Table 6 About Here]}

In Table 7 we show the net modernisation scores for each of the three main parties according to the electoral status of constituencies. It is clear, first, that the balance between traditional and modern techniques has shifted towards the latter in all types of seat. By 2005, it was only Conservative campaigns in their safe seats, which were significantly more traditional than the other categories from 1992, that traditional activities were given more weight than modern methods. Secondly, for both the Conservatives and the Liberal Democrats it is in seats that were neither held nor targeted that the balance is most firmly in the direction of modern campaigning. Although in both cases scores in these hopeless seats are rarely significantly different from those in target seats, this itself is evidence that modern techniques - the use of telephones and the like - can be a sort of substitute for volunteer personnel. Where there simply aren't enough volunteers to canvass door-to-door or deliver leaflets then a few telephone canvassers can fill the gap. On the other hand, modern methods may be seen to be simply more effective and in that case we should expect to see them introduced more quickly into target seats. This is the pattern found in Labour campaigning - from 1997 campaigns in target seats are weighted more strongly in the direction of modern techniques than is the case in the other categories, a pattern confirmed by significance tests using the 1997-2005 index.

\section{[Table 7 About Here]}

Our data clearly show, then, that the use of traditional campaign techniques has been declining while modern methods have become more prevalent. Data not presented here show that for all parties the use of modern techniques is always most developed in target seats. However, these seats also have strong traditional campaigns - volunteer workers often flood into them from the surrounding area - so that it is only in the case of the Labour party that 
targets show the strongest bias in favour of modernisation. For the other parties, modernisation is more clearly a response to the declining availability of campaign workers.

Modern techniques have not replaced traditional ones in British constituency campaigning, as predicted in stage 3 of the framework introduced above, but the balance has certainly shifted to the extent that what might be described as a modern approach to campaigning is now more prevalent. British parties, we suggest therefore, are now somewhere between stages 2 and 3 in the typology of changes in campaigning.

\section{Resource}

\section{Centralisation}

There is much qualitative evidence indicating that during the 1990s and after constituency campaigns in Britain came increasingly to be directed and managed by professionals at central party headquarters (Denver et al., 2003; Fisher, Denver and Hands, 2006a). Similar trends have also been observed in Australia and New Zealand (Ward, 2003; Denemark, 2003). What has emerged is a new and much stronger relationship between the national and local campaigns. National party professionals now seek to exercise much greater influence and control over local campaigning by managing key constituency campaigns in crucial respects and integrating them much more closely into the national effort. Local campaign strategies are developed centrally and in tandem with the parties' overall national campaign strategies. The centre appoints special campaign organisers in key seats (or provides centrally-paid agents in the case of the Conservatives) and is involved in local campaigns in a variety of other ways - by organising direct mail operations and telephone canvassing from outside the constituency; for example. These changes began first, and have gone furthest, in the Labour party but both the Conservatives and, to a lesser extent, the Liberal Democrats have followed Labour's lead. As has been argued elsewhere, in many respects the initiative in local campaigning in target seats has passed from the local party to the parties' national headquarters (Denver et al. 1998).

Fisher, Denver and Hands (2006a) sought to analyse this trend by constructing quantitative scales to measure the degree of central involvement in constituency campaigns. The results generally confirmed the arguments advanced on the basis of qualitative data - centralisation was on the increase, Labour had taken the lead in this respect but the Conservatives were catching up. Although central involvement had also increased in the case of the Liberal 
Democrats, it had not gone as far as in the other parties, partly due to a simple lack of resources but also in line with the party's decentralising ethos. This analysis also found that central involvement was heavily targeted - the central involvement index scores were significantly higher in target seats than in the other categories. Not unexpectedly, central coordinating efforts were strongly focused on the campaigns that were most electorally significant.

In this section, we update the previous discussions of increasing central involvement in constituency campaigns by adding material from the 2005 general election. The parties' strategies in that election certainly suggest a further development of centralising trends, especially on the part of the Conservatives and Labour (Fisher et al., 2007). Both sought to present their national message within a local context. To that end, in campaign material circulated within a constituency policies were frequently not described in a national context but presented as proposals which would have a particular impact in the constituency concerned. This was achieved principally though the extensive use of direct communication techniques by both Labour and the Conservatives to contact key voters in key seats. Both parties had large communication centres from which key voters were sent direct mail and contacted by telephone. In effect, national headquarters were playing an ever-greater role in communicating the messages of the constituency campaigns. In a particular innovation, many voters were telephoned not by an individual in a call centre, but by an automated phone system, allowing parties to collect vote intention data (or 'Voter ID') and other relevant information more quickly and more cheaply than before. Arguably, by 2005 the 'ground war' in the constituencies had come to be seen as more important than the 'air war' waged at national level. Fisher (2005) shows that the 'national' campaigns of all three major parties were strongly focused on target seats and that regional media advertising was as important, if not more so than that undertaken at national level. This is further confirmation of the importance that the parties now attach to local campaigning but, significantly, it is nationallyco-ordinated constituency campaigning that is dominant rather than locally organisedcampaigning.

We illustrate these trends, using quantitative measures, in Table 8. We have two measures of centralisation - one covering the whole period 1992-2005 and a second that reflects changes in campaign activities (especially the development of telephone canvassing) for which data are available only from 1997. Details of the variables used are given in the Appendix. The 
data shown here refer only to English constituencies since survey responses to questions about 'national' headquarters are likely to be less reliable and consistent in Scotland and Wales. The data show, as expected, that the level of central involvement in constituency party campaigns has grown steadily - for both the Conservatives and the Liberal Democrats there has been an election-on-election increase which is statistically significant, (though only using the 1997-2005 index in the case of the Liberal Democrats). Labour was well ahead of the other parties in the degree of central involvement in 1992 and has more or less continued at the same overall level with a slight but significant dip in 2005. For all parties, central involvement is greatest in target seats - usually by some margin - with the difference between these and non-targets being especially marked in the case of Labour campaigns. Using either index Labour's scores in target seats are significantly greater than in other seat types in each election. This was also broadly true for the Conservatives from 1997 onwards with the odd exception (such as the 1992-2005 index in 2005). For the Liberal Democrats, targets and held seats had significantly higher scores than those not held or targeted in both 2001 and 2005 using the 1997-2005 index.

While central involvement in constituency campaigns has certainly increased, then, this development is most marked in target seats. In hopeless seats, in contrast, central involvement, if anything, has declined over the period. Labour is the most 'centralised' of the parties in that Labour campaigns in their targets consistently have the highest index score as well as greatest differentiation between target and non-target seats. In the other parties, it would seem some residual local resistance remains to what is seen as central 'interference'. This may, in part, be explained by differing party 'cultures'. Conservative constituency associations, for example, have traditionally enjoyed significant autonomy, whilst the ethos of the Liberal Democrats leans more towards decentralization. Nonetheless, all three parties are clearly moving towards increased levels of centralization in constituency campaigning.

In terms of the analytical framework described above, British campaigns have certainly reached Stage 2 with respect to central involvement. In target seats, however, there are indications of a move to Stage 3. In 2005 in these seats there was, of course, considerable central scrutiny but, as previously indicated, decentralisation involved tailoring publicity about policy to the constituency. Despite the presence of centrally-appointed organisers and centrally-controlled activities such as direct mail and telephone canvassing, campaigns in 
these seats also remain relatively strong in terms of 'foot slogging' activities on the ground, which are inherently decentralised.

\section{[Table 8 About Here]}

\section{Staffing}

Overwhelmingly, the work related to constituency campaigning is carried out by volunteers. However, the modernisation and centralisation of campaigns have involved an increase in the numbers of paid staff with responsibilities related to the local effort - mainly staff at the parties' national headquarters and in national call centres. Indeed, Webb and Fisher (2003:10) have noted that there have been substantial increases in the proportion of all kinds of paid staff relative to members in both the Conservative and Labour parties. Even 'on the ground', however, there have also been significant changes with paid staff playing an increasingly significant role in some constituency campaigns.

Since the late nineteenth century, election agents have been key figures in constituency campaigns. However, the development of national campaigns during the twentieth century and, most critically, cost effective forms of mass communication (especially television) meant that the constituency campaign - and hence also the local party agent - declined in status and significance. Nonetheless, the number of full-time agents remained notably large until the 1950s (Fisher, Denver and Hands, 2006c) although only those constituency parties that could afford one employed an agent. Overall, the organisation of staff for constituency campaigns was almost entirely localised. From the 1950s, however, the numbers of full-time agents declined steeply. The trend was very much towards volunteer agents - typically people with plenty of knowledge of the local political scene and experience of working in election campaigns - appointed by candidates simply to run a campaign. In terms of resources, this period clearly represented what we have called Stage 1 in the development of constituency campaigning - voluntary activity plus assistance from the central (and regional) party bureaucracy.

During the 1990s, as we have seen, the parties began to re-assess the importance of constituency campaigning and as a result central party staff began to take constituency campaigning much more seriously. Party managers realised that there was an important job to be done in the constituencies but they also increasingly came (or were forced) to the view that 
employing full-time agents locally or relying entirely on voluntary agents was not necessarily the best way to do it - even although the law still requires the appointment of a local agent.

One response from the parties was to try to 'professionalise' the volunteers - providing programmes of training to develop the organisational skills and abilities that can profitably be brought to bear at constituency level. Labour, for example, introduced a professional training programme for campaign organisers in 1999, which involved a formal award upon completion (Webb and Fisher, 2003: 18). In addition, however, all three parties have looked for other ways to ensure that professional expertise is available to key constituency campaigns. For example, since 1997 the Conservatives have employed and part-financed local agents from the centre. In addition, following the 1997 election, the party abolished its regional tier of organisation and moved to a system in which Area Campaign Directors had responsibility for a number of constituencies. Labour began to appoint special organisers in 1992 - people centrally recruited, trained and appointed on short-term contracts - to particular target constituencies (or groups of constituencies) to oversee election preparations and then to organise the campaign itself. The Liberal Democrats have not had the resources to undertake programmes on this scale but, even so, by 2001 party headquarters provided financial assistance to allow paid agents or part-time organisers to be employed in key seats and two Assistant Campaign Directors were appointed at national level to assist and encourage the development of effective constituency campaign organisations (Fisher, Denver and Hands, 2006c).

In sum, it would seem that in this respect parties have moved to Stage 2 of our framework and are displaying some characteristics of Stage 3. Parties have professionalized their staff (both paid and volunteer) at both national and local levels (Webb and Fisher, 2003; Fisher, Denver and Hands, 2006c). Moreover, in the case of Labour at least, in target seats having professional staff on short-term contracts is now almost the norm and the Conservatives and Liberal Democrats have also started to move towards short-term contract staff. It remains the case, however, that in most constituencies the brunt of the burden of organising and running campaigns falls upon local volunteers and full-time staff at party headquarters.

\section{Feedback}

Parties regularly seek feedback from voters in order to monitor their performance. During election campaigns, however, the need for relevant information is heightened and voter 
reactions are monitored more or less continuously. When parties are at Stage 1 in our typology of campaign development the main source of such feedback is traditional doorstep canvassing. However, for a variety of reasons, we would expect this to be of diminishing importance. Parties have fewer members and other workers to participate in canvassing and there is a growing number of alternative forms of gathering feedback from voters, which are likely to be more efficient. Telephone canvassing, for example, requires no travelling between addresses and usually callers employ a standard script so that a standard set of information is collected from each person contacted. Automated calls make the process even more efficient. There are debates about whether such methods are desirable or whether voters respond well to them (Gerber \& Green, 2000, 2001; Pattie \& Johnston, 2003) but there is no doubt that these methods are on the increase.

Table 9 charts the decline in doorstep canvassing. It shows the mean percentage of the electorate in each constituency that was canvassed on the doorstep in each election since 1992 across all types of seat. Notwithstanding a small revival for all parties in $2005,^{3}$ the overall trend is clear (and statistically significant) - over these four elections the proportion of the electorate canvassed locally has declined. And, despite the decline, familiar patterns emerge. With the exception of 1997, the extent of Labour canvassing in target seats was significantly greater than in other seats. The Liberal Democrats canvassed to a significantly lesser extent in unwinnable seats than in those targeted and held in 2001 and 2005. The same pattern held for the Conservatives in all four elections.

\section{[Table 9 About Here]}

In Table 10, we examine the extent to which more modern feedback methods have been employed, such as telephone canvassing and direct mail. The index used here was created in the same way as others previously described and details of variables used are in the Appendix. Given the emphasis on telephone canvassing, data for this index are available only from 1997 onwards. As expected, modern and perhaps more 'scientific' forms of voter feedback have come increasingly to the fore. In all parties, there has been a clear and statistically significant growth in modern feedback techniques since 1997 - especially in

\footnotetext{
The rise in 2005 is amplified slightly by the less robust Conservative figure
} 
target seats - demonstrating that they have moved from Stage 1 to Stage 2 of the relevant part of the development framework, at least.

Qualitative evidence also supports this argument. In 2005, for example, Labour used DVDs to target weak and undecided Labour voters. All viewers of the DVD would see an opening film based upon their constituency (featuring the MP/candidate and work undertaken in the local community). There was then a menu of additional features including four local stories about health, the economy, crime and education, and a national message from Tony Blair. The DVD also contained a feedback mechanism, which enabled the party to ascertain how much of the DVD was viewed and evidently many key voters watched it in its entirety (Fisher et al., 2005: 19).

In the same election, the Conservatives increased their use of polling and focus group data. Daily tracking polls were undertaken among key voters in target seats, focussing on salient issues, candidate recognition and assessments of the party leaders. Focus group research was also employed to check on how campaign messages were being received and the party used the results to 'tweak messages' on particular issues (such as crime and immigration) in an attempt to attract undecided voters (Fisher et al., 2005: 20). Moreover, in all parties, the central monitoring of local campaigns has increased significantly, so that even individual constituency campaigns can be 'tweaked' in response to local concerns. All of this suggests that, in terms of feedback, British parties are well on the way to Stage 3 of our typology, if not already there.

\section{[Table 10 About Here]}

\section{Thematic}

\section{Tours by Party Leaders and Key Party Figures}

Tours by key party figures have long been a highly visible component of constituency party campaigning. Gladstone was the first major politician to 'stump the country' in the nineteenth century, delivering speeches directed at the whole country (and reported in the press) but with a local twist designed to make the speeches more relevant to his audience (Hanham, 1978: 202-4). In the 1950 election, Clement Attlee (the Prime minister) undertook a 1,000 mile tour around Britain being driven in a pre-war (and far from deluxe) family saloon by his wife (Nicholas, 1951: 93-4). 
Attlee's tour, during which he reportedly visited seven towns a day, was focussed on Labour's key electoral regions (Nicholas, 1951:90). At the same election, Winston Churchill also spoke in a number of constituencies - amongst them, Plymouth Devonport, chosen apparently because of the highly newsworthy contest there between Randolph Churchill and Michael Foot (Nicholas, 1951: 94). This mirrors in some ways the 1966 campaign, in which Conservative leadership visits to marginals tended to be a function of personal contacts, rather than a centrally co-ordinated effort by the party (Butler and King, 1966: 194). Indeed, Denver and Hands (1997:111) noted that as late as 1992 personal favours could still explain some constituency visits by the party hierarchy.

However, as Butler and Kavanagh (1974: 224) suggest, from 1974 there was a far greater emphasis on focussing leadership tours on marginal seats, rather than on regions or newsworthy contests. In advance of the February 1974 election, both major parties had drawn up short lists of key marginals in advance and during the campaign itself, all parties tried to direct their prominent national speakers to these seats (Butler and Kavanagh, 1974: 224-6). That said, some local parties did not entirely support this strategy, claiming that the visits were too disruptive - a problem that Denver and Hands (1997: 112) also reported in the 1992 election. Nonetheless, from February 1974 onwards, it was clear that party leadership tours were planned around marginal seats to a far greater degree than previously. Butler and Kavanagh (1975: 226) say that, in the October election of the same year, Conservative marginal seats were given 'a special claim on front bench speakers', and by 1979 the practice was well established (Butler and Kavanagh, 1980: 308). Clearly, then, by 1979 party leadership tours had moved from stage 1 to stage 2 of the campaigning development framework - from nationwide whistle-stop tours to a focus on target seats.

Our surveys of party agents allow us to test the extent to which these practices have evolved since 1992 and relevant data are shown in Table 11. No question was asked on this aspect of campaigning in 2001, and while it was restored in 2005, the question about leadership visits asked only whether they had occurred, rather than about the frequency of visits as in 1992 and 1997. Nevertheless, the data do provide some indication of change over time.

As anticipated, in all parties senior figures are far more likely to visit target seats than other constituencies. In the cases of Labour and the Liberal Democrats, the concentration on target 
seats appears to have become more marked, with declines in visits to seats that were neither targeted nor held. The differences between target and non-target seats for Labour are particularly marked - especially in 1997 when every target seat among our responding constituencies received a visit and the mean number of visits was an astonishing 6.7. In 2005, there was something of an increase in visits to safer Labour-held seats. This can probably be explained by the fact that Labour was on the defensive not only from its opponents, but also from disillusioned Labour supporters. Appearances by party 'names' in safe seats were probably organised, therefore, to 'rally the troops'.

The data for the Conservatives are a little more puzzling. It is true that in all three elections senior party figures were far more likely to visit target seats and in 1992 and 1997, visited almost all of them. The dip in the proportion of target seats visited in 2005 is almost certainly a function of the lower response rate from Conservative agents in that year. However, in all three elections, it is notable that 'hopeless' seats were relatively well treated in terms of leadership visits - more so than safe seats. Given that, as already mentioned, an underlying problem with Conservative campaigns has been that they tend to mount needlessly strong campaigns in their safest seats, this is a particularly peculiar result. It may be a consequence of the fact that in 2005 the Conservatives needed to be on the offensive - to make serious efforts even in seats that were not among their best prospects - although it may also suggest that Labour and the Liberal Democrats are simply better than the Conservatives at targeting leadership visits. Whatever the reason, it suggests that the extent to which parties are moving between Stage 2 and 3 of the typology varies somewhat - certainly Labour would appear to be ahead of the Conservatives in this respect.

\section{[Table 11 About Here]}

\section{Targeting of Voters}

One of the consequences of class and partisan dealignment is that parties are no longer able to rely on core groups of voters for almost automatic support. Thus, of necessity, parties are likely to move on from Stage 1 of our typology although, as evidence from New Zealand illustrates, different countries can experience dealignment at completely different times (Denemark, 2003: 603). In the British case, dealignment has been progressing for at least thirty years so it is little surprise that parties no longer focus their campaigning activities on maintaining support among specific social categories. The question is whether in this respect 
local campaigning is best characterised as being at Stage 2 (mobilizing voters across all categories) or Stage 3 (targeting specific groups of voters). Table 12 provides some indication of the extent of group targeting conducted at constituency level. The data derive from responses to a question asking how much effort local parties put into targeting specific groups. Answers were measured on a five-point scale (a higher score indicating more effort) and the table shows mean responses. Some groups are targeted for special attention by all parties as a matter of course - first-time voters and postal voters, for example - but there is often some differentiation in respect of other groups. In 2005, for example, the Conservative focussed in particular on pensioners; Labour on pensioners and ethnic minorities, and the Liberal Democrats on pensioners and students (Fisher et al., 2005).

Nevertheless, the data in Table 12 suggest that there has been little overall change over the four elections in the effort made by parties in targeting specific groups, although the Liberal Democrats and Conservatives appear to have put in significantly more effort in 2005 . If the data are disaggregated by target status then familiar patterns emerge - usually much more effort takes place in target seats. This is especially true of Labour until 2005, when there appears to have been greater efforts to target specific groups of voters in safe seats. Again, this is likely to have been a function of the fact that Labour was on the defensive in this election.

\section{[Table 12 About Here]}

However, the effort undertaken at local level provides only a partial picture of attempts to influence specific groups of voters within constituencies. As we have seen, the parties' headquarters have become increasingly important in constituency campaigns and have contributed directly via telephone canvassing and direct mail, over and above purely local activities. Interviews with party professionals suggest that in terms of these nationallydirected efforts the parties have certainly moved strongly to targeting specific categories of voters. Labour was first to move significantly in this direction in preparation for the 1997 election. Telephone banks were established some 18 months before the election and party workers across the country used them to contact voters in key seats. Using a centrallydesigned script-cum-questionnaire, callers allocated voters to one of a number of categories and this information was then used to identify target groups of voters, comprising about 15 per cent of the electorate in the relevant constituencies. Subsequently, these voters were re- 
contacted by telephone, sent appropriate direct mail communications at regular intervals and visited in person by local campaign workers (Denver et al., 2003: 543). In the 2001 and 2005 elections these techniques were further refined. In 2001, the party began to make use of demographic data relating to neighbourhoods, combining them with a database of voter identification, which enabled not only further refinement of the target groups to be contacted from the centre, but also provided the basis for guidelines issued to constituencies detailing which groups and areas should receive special attention (Denver et al., 2003: 544). In 2005, the process was taken even further, with young people, women and families, and Muslims receiving particular attention (Fisher et al., 2005: 13).

The Conservatives have also employed this sort of approach and although they were initially not as advanced as Labour, by 2005 they had effectively caught-up and were enthusiastically prosecuting a strategy of targeting key groups in target seats - in particular pensioners and ethnic minorities (Fisher et al., 2005: 12). The Liberal Democrats, in contrast, have made far less use of the kinds of technology employed by Labour and the Conservatives. This was principally a function of cost - the party is notably less wealthy than the other two and such methods require investment at least two years before an election. Thus, although the Liberal Democrats were better funded than ever before for the 2005 campaign, financial support arrived too late to be invested in such technology (Fisher, 2005: 184). Nevertheless, there is still evidence that by 2005, the party had also reached Stage 3 in terms of targeting voters. At that election the party tried in particular to engage and mobilise students by targeting university campuses (with the assistance of Liberal Democrat student societies), and by targeting mail specifically at students (Fisher et al., 2005:14).

\section{Conclusions}

Studies of district-level campaigning have clearly demonstrated that local efforts can have a significant electoral effect and that concentrating on national campaigns - characteristic of much of the literature on campaigning - gives an incomplete picture of elections. Typologies describing the development of national campaigns are relatively common and are, of course, important in their own way. It also remains the case that national and local strategies are closely intertwined but we suggest that a distinct framework applying to district-level campaigning is needed to analyse changes in local campaigning in a comparative context even if it is informed by previous work on national campaigning. The use of the framework introduced here allows for an examination of many aspects of campaigning that are 
specifically pertinent to the district level which will often not be captured by national level studies. Moreover, the disaggregation of campaign styles shows how levels of income do not have uniform effects on parties' ability to campaign. During the period studied here, for example, Labour has typically been the wealthiest party at national level (Fisher, 2005). Yet, the Conservatives have still been able to mount strong campaigns. More telling is the case of the Liberal Democrats who are markedly less wealthy than either Labour or the Conservatives. Yet, that party has been able to mount successful campaigns though strategic use of resources. In sum, therefore, the framework introduced here represents an attempt to better classify the distinct and important developments that have occurred in district-level campaigning.

Applying the framework to the British case shows quite clearly that there are variations in campaign development across the different parties and also according to the particular aspect of campaigning being considered. Moreover, there is further variation depending upon the electoral status of the constituency. Applying it in other systems should help researchers to make systematic cross-national comparisons. Developments in constituency campaigning in Britain are summarized in Table 13 which suggests that, across the various stages of development, Labour is the most 'modern' in its approach to campaigning, just pipping the Conservatives in respect of staffing and the use of leading party figures. The Conservatives, in turn, are just ahead of the Liberal Democrats, although the differences are not great. In our previous work, reliant on qualitative evidence, we suggested that while Labour had taken the lead in developing constituency campaigning, the other major parties were 'catching-up' (Denver et al., 2003). This suggestion is borne out by the various analyses presented here. It might be expected that the Conservatives would catch up - the major parties keep an eye on one another's activities and are happy to copy good ideas - but it is interesting to find that the Liberal Democrats too have made significant advances, given their relative lack of resources, especially finance. In fact, the summary data in Table 13, together with the details previously discussed suggest that all three major British parties have adapted well to the changed electoral, organisational and technical circumstances, though it may be the case that Labour's progress has 'stalled' a little. Nevertheless, all three have modernised their constituency campaigns and doubtless will continue to do so as new circumstances arise and new ideas emerge about how to achieve the fundamental task for all parties - getting people to vote for them. 
Yet these trends also have significant implications. In all parties there is a move away from traditional grass-roots activism and towards more modern and centrally directed campaigning. This is a clear example of a more general move from mass membership-based parties to 'electoral-professional' parties. There are also wider implications. First, the evident targeting strategy of parties is likely to amplify the differential levels of electoral turnout between marginal and non-marginal seats. If that occurs, the effect will be likely to be a depression in aggregate levels of turnout, together with disenchantment of voters in seats not targeted by parties. Of course, the parties cannot be blamed for this - it is an entirely rational response to the logic of a first past the post electoral system. Secondly, the targeting strategy in combination with greater centralisation and modern campaign methods may put pressure on the regulatory framework. In Britain, national and district level campaigning are regarded as being separate for regulatory purposes. How far that distinction can remain meaningful, however, is a moot point. On a more positive note, however, the strategies employed by parties such as voter differentiation, feedback and local focus as demonstrated here may actually illustrate a greater willingness on the part of parties to note and act upon voters' concerns. Thus, the stages of development in district-level campaigning should be seen as just that, with implications that be both positive and negative.

\section{[Table 13 About Here]}


Figure 1: Three Stages in the Development of District-level Election Campaigning

\begin{tabular}{|c|c|c|c|}
\hline & Stage 1 & Stage 2 & Stage 3 \\
\hline Technical & $\begin{array}{l}\text { - Short-term campaign } \\
\text { preparations } \\
\text { Sporadic use of } \\
\text { technology. } \\
\text { Campaigning is } \\
\text { largely traditional } \\
\text { and labour intensive }\end{array}$ & $\begin{array}{l}\text { - Longer-term } \\
\text { preparations } \\
\text { including specialist } \\
\text { campaign committee } \\
\text { at centre } \\
\text { - Technology widely } \\
\text { used alongside } \\
\text { traditional campaign } \\
\text { techniques }\end{array}$ & $\begin{array}{l}\text { - Permanent campaign } \\
\text { with specialist } \\
\text { campaign department } \\
\text { at centre } \\
\text { - Technology replaces } \\
\text { traditional campaign } \\
\text { techniques }\end{array}$ \\
\hline Resource & $\begin{array}{l}\text { Decentralized with } \\
\text { little standardization } \\
\text { Voluntary activity } \\
\text { and use of traditional } \\
\text { party bureaucracy } \\
\text { - Impressionistic } \\
\text { feedback based } \\
\text { mainly on canvassing }\end{array}$ & $\begin{array}{l}\text { Centralized and } \\
\text { standardized } \\
\text { Voluntary workers } \\
\text { directed by party } \\
\text { professionals } \\
\text { More scientific } \\
\text { sources of feedback, } \\
\text { including opinion } \\
\text { polls }\end{array}$ & $\begin{array}{l}\text { Decentralization of } \\
\text { operation with } \\
\text { central scrutiny } \\
\text { - } \begin{array}{l}\text { Professional staff on } \\
\text { short-term contracts }\end{array} \\
\text { - } \begin{array}{l}\text { Greater range of } \\
\text { polling techniques } \\
\text { making greater use } \\
\text { of feedback }\end{array}\end{array}$ \\
\hline Thematic & $\begin{array}{l}\text { Whistle-stop tours by } \\
\text { party leaders } \\
\text { - Focus on mobilising } \\
\text { the vote of } \\
\text { supporters }\end{array}$ & $\begin{array}{l}\text { Tours by party } \\
\text { leaders focussed on } \\
\text { target seats } \\
\text { Mobilizing voters } \\
\text { across all categories }\end{array}$ & 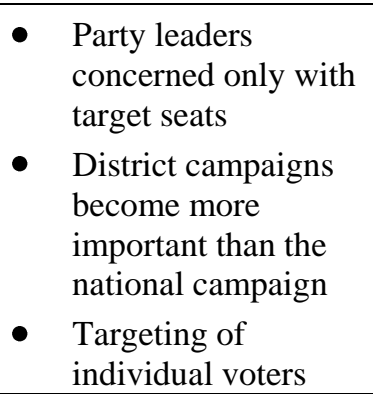 \\
\hline
\end{tabular}

Source: Derived from Farrell and Webb, (2002: 104)

Table 1: Long-Term Preparation in British Constituency Campaigns

1992

1997

\section{Conservative \\ Labour}

Lib Dems

$\begin{array}{rrrr}118 & - & 112 & (114) \\ 112 & - & 112 & (111) \\ 91 & - & 84 & (83)\end{array}$

2001

2005

$\begin{array}{rrr}114 & (116) & 130 \\ 100 & (103) & 98 \\ 78 & (78) & 82\end{array}$

Note: Figures in parenthesis are for the index calculated for the period 1997-2005. For the numbers on which this and all subsequent tables are based see the Appendix. 
Table 2: Long-Term Preparation in British Constituency Campaigns by Seat Status

$$
\begin{array}{llll}
1992 & 1997 & 2001 & 2005
\end{array}
$$

\begin{tabular}{|c|c|c|c|c|c|c|c|c|}
\hline \multicolumn{9}{|l|}{ Conservative } \\
\hline Held Not Target & 121 & - & 118 & $(121)$ & 122 & $(125)$ & 131 & $(136)$ \\
\hline Target & 121 & - & 124 & (130) & 125 & (130) & 128 & (136) \\
\hline Not Held Not Target & 112 & - & 102 & (103) & 99 & $(100)$ & 130 & $(135)$ \\
\hline \multicolumn{9}{|l|}{ Labour } \\
\hline Held Not Target & 108 & - & 111 & $(109)$ & 104 & (104) & 105 & $(110)$ \\
\hline Target & 124 & - & 124 & (134) & 115 & (110) & 111 & $(121)$ \\
\hline Not Held Not Target & 106 & - & 108 & (106) & 88 & (89) & 83 & $(83)$ \\
\hline \multicolumn{9}{|l|}{ Lib Dems } \\
\hline Held Not Target & * & - & $*$ & $*$ & 108 & $(103)$ & 115 & $(116)$ \\
\hline Target & 110 & - & 116 & (119) & 116 & (120) & 119 & $(127)$ \\
\hline Not Held Not Target & 89 & - & 81 & $(81)$ & 74 & (73) & 73 & (74) \\
\hline
\end{tabular}

Note: Figures in parenthesis are for the index calculated for the period 1997-2005.

* Too few cases for analysis.

Table 3. Mean number of party members per constituency, 1992-2005

$\begin{array}{lrrrr} & \mathbf{1 9 9 2} & \mathbf{1 9 9 7} & \mathbf{2 0 0 1} & \mathbf{2 0 0 5} \\ \text { Conservative } & 1,542 & 732 & 646 & 892 \\ \text { Labour } & 444 & 592 & 475 & 349 \\ \text { Liberal Democrats } & 166 & 162 & 130 & 157\end{array}$

Table 4. Trends in Traditional Campaigning

$\begin{array}{lrrrr} & \mathbf{1 9 9 2} & \mathbf{1 9 9 7} & \mathbf{2 0 0 1} & \mathbf{2 0 0 5} \\ \text { Conservative } & 131 & 109 & 107 & 127 \\ \text { Labour } & 116 & 115 & 98 & 97 \\ \text { Liberal Democrats } & 87 & 83 & 77 & 89 \\ \text { All } & 109 & 103 & 93 & 97\end{array}$

Table 5. Trends in Campaign Modernisation

\begin{tabular}{lrrrrrrrrr} 
& $\mathbf{1 9 9 2}$ & \multicolumn{9}{c}{$\mathbf{1 9 9 7}$} & \multicolumn{2}{c}{$\mathbf{2 0 0 1}$} & \multicolumn{2}{c}{$\mathbf{2 0 0 5}$} \\
Conservative & 99 & -- & 109 & $(107)$ & 111 & $(110)$ & 132 & $(133)$ \\
Labour & 92 & -- & 109 & $(103)$ & 112 & $(107)$ & 112 & $(109)$ \\
Lib Dems & 72 & -- & 87 & $(80)$ & 93 & $(85)$ & 106 & $(99)$ \\
All & 85 & -- & 101 & $(96)$ & 105 & $(100)$ & 111 & $(107)$
\end{tabular}

Note: Figures in parenthesis are for the index calculated for the period 1997-2005. 
Table 6. Net Modernisation Scores (Traditionalism - Modernisation )

\begin{tabular}{lrrrrrrrr} 
& $\mathbf{1 9 9 2}$ & \multicolumn{3}{c}{1997} & \multicolumn{2}{c}{$\mathbf{2 0 0 1}$} & \multicolumn{2}{c}{$\mathbf{2 0 0 5}$} \\
Conservative & 32 & - & 0 & $(2)$ & -5 & $(-3)$ & -5 & $(-6)$ \\
Labour & 25 & - & 6 & $(12)$ & -14 & $(-9)$ & -16 & $(-12)$ \\
Lib Dems & 15 & - & -3 & $(4)$ & -17 & $(-9)$ & -17 & $(-10)$ \\
All & 24 & - & 2 & $(7)$ & -13 & $(-8)$ & -14 & $(-10)$
\end{tabular}

Note: Figures in parenthesis are for the index calculated for the period 1997-2005.

Table 7. Net Modernisation Scores (Traditionalism - Modernisation ) by seat status

\begin{tabular}{|c|c|c|c|c|c|c|c|c|}
\hline \multirow[b]{2}{*}{ Conservative } & \multicolumn{2}{|c|}{1992} & \multicolumn{2}{|c|}{1997} & \multicolumn{2}{|c|}{2001} & \multicolumn{2}{|c|}{2005} \\
\hline & & & & & & & & \\
\hline Held Not Target & 50 & - & 12 & (13) & 5 & (6) & 4 & (4) \\
\hline Target & 12 & - & -8 & $(-8)$ & -8 & $(-11)$ & -12 & $(-15)$ \\
\hline Not Held Not Target & 15 & - & -7 & $(-5)$ & -10 & $(-6)$ & -38 & $(-36)$ \\
\hline Labour & & & & & & & & \\
\hline Held Not Target & 32 & - & 10 & (18) & -12 & $(-5)$ & -14 & $(-11)$ \\
\hline Target & 24 & - & 3 & (1) & -15 & $(-16)$ & -18 & $(-20)$ \\
\hline Not Held Not Target & 21 & - & 3 & (11) & -15 & $(-8)$ & -16 & $(-10)$ \\
\hline Lib Dems & & & & & & & & \\
\hline Held Not Target & $*$ & - & $*$ & $*$ & -4 & $(1)$ & -7 & $(-5)$ \\
\hline Target & 40 & - & 20 & (24) & -9 & $(-6)$ & -3 & $(-5)$ \\
\hline Not Held Not Target & 13 & - & -5 & (2) & -18 & $(-9)$ & -16 & $(-10)$ \\
\hline
\end{tabular}

Note: Figures in parenthesis are for the index calculated for the period 1997-2005.

* Too few cases for analysis.

Table 8: Central Involvement in Constituency Campaigning

\begin{tabular}{|c|c|c|c|c|c|c|c|c|}
\hline \multirow[b]{2}{*}{ Conservative } & \multicolumn{2}{|c|}{1992} & \multicolumn{2}{|c|}{1997} & \multicolumn{2}{|c|}{2001} & \multicolumn{2}{|c|}{2005} \\
\hline & 100 & - & 102 & $(100)$ & 112 & $(110)$ & 121 & $(122)$ \\
\hline Held Not Target & 98 & - & 95 & $(92)$ & 107 & (104) & 120 & (117) \\
\hline Target & 112 & - & 127 & $(125)$ & 127 & (129) & 129 & (137) \\
\hline Not Held Not Target & 98 & - & 101 & $(98)$ & 103 & (101) & 95 & (92) \\
\hline Labour & 108 & - & 107 & $(106)$ & 107 & (108) & 101 & $(102)$ \\
\hline Held Not Target & 102 & - & 99 & $(95)$ & 102 & $(100)$ & 97 & (97) \\
\hline Target & 121 & - & 150 & (159) & 130 & (138) & 134 & $(145)$ \\
\hline Not Held Not Target & 103 & - & 100 & $(97)$ & 100 & (98) & 92 & (91) \\
\hline Lib Dems & 86 & - & 86 & $(86)$ & 91 & (89) & 92 & (92) \\
\hline Held Not Target & $*$ & - & * & $*$ & 111 & (106) & 108 & (112) \\
\hline Target & 92 & - & 130 & $(128)$ & 116 & (117) & 112 & (116) \\
\hline Not Held Not Target & 85 & - & 84 & $(83)$ & 89 & $(87)$ & 88 & $(87)$ \\
\hline
\end{tabular}

Note 1: Figures in parenthesis are for the index calculated for the period 1997-2005.

Note 2: Figures calculated for English seats only.

* Too few cases for analysis. 
Table 9. Mean Percentage of Electorate Canvassed On the Doorstep

$\begin{array}{lrrrr} & \mathbf{1 9 9 2} & \mathbf{1 9 9 7} & \mathbf{2 0 0 1} & \mathbf{2 0 0 5} \\ \text { Conservative } & 42 & 27 & 27 & 37 \\ \text { Held Not Target } & 50 & 37 & 36 & 41 \\ \text { Target } & 48 & 30 & 35 & 38 \\ \text { Not Held Not Target } & 25 & 19 & 19 & 8 \\ & & & & \\ \text { Labour } & 34 & 26 & 18 & 20 \\ \text { Held Not Target } & 37 & 26 & 17 & 23 \\ \text { Target } & 53 & 29 & 29 & 33 \\ \text { Not Held Not Target } & 21 & 26 & 13 & 10 \\ & & & & \\ \text { Lib Dems } & 12 & 12 & 8 & 11 \\ \text { Held Not Target } & * & * & 19 & 21 \\ \text { Target } & 29 & 33 & 19 & 21 \\ \text { Not Held Not Target } & 11 & 10 & 7 & 8 \\ \quad \text { Too few cases for analysis } & & & \\ & & & & \\ & & & \end{array}$

Table 10. Index of Modern Feedback Use in Constituency Campaigns

$\begin{array}{lrrr} & \mathbf{1 9 9 7} & \mathbf{2 0 0 1} & \mathbf{2 0 0 5} \\ \text { Conservative } & 109 & 108 & 128 \\ \text { Held Not Target } & 112 & 111 & 116 \\ \text { Target } & 133 & 133 & 146 \\ \text { Not Held Not Target } & 98 & 88 & 137 \\ & 105 & 109 & 113 \\ \text { Labour } & & & \\ \text { Held Not Target } & 95 & 104 & 118 \\ \text { Target } & 160 & 151 & 153 \\ \text { Not Held Not Target } & 95 & 90 & 89 \\ & & & \\ \text { Lib Dems } & 80 & 79 & 92 \\ \text { Held Not Target } & * & 88 & 114 \\ \text { Target } & 111 & 121 & 137 \\ \text { Not Held Not Target } & 77 & 76 & 82 \\ \text { * Too few cases for analysis } & & \end{array}$


Table 11: Visits to Constituencies by Senior Party Figures

\begin{tabular}{lrrrrr} 
& \multicolumn{2}{c}{1992} & 1997 & $\mathbf{2 0 0 5}$ \\
Conservative & & & & & \\
Held Not Target & $52 \%$ & $(1.1)$ & $45 \%$ & $(1.0)$ & $3 \%$ \\
Target & $98 \%$ & $(4.7)$ & $98 \%$ & $(4.5)$ & $57 \%$ \\
$\begin{array}{l}\text { Not Held Not Target } \\
\text { Labour }\end{array}$ & $60 \%$ & $(1.7)$ & $69 \%$ & $(1.8)$ & $33 \%$ \\
Held Not Target & $28 \%$ & $(0.7)$ & $22 \%$ & $(0.5)$ & $37 \%$ \\
Target & $87 \%$ & $(3.8)$ & $100 \%$ & $(6.7)$ & $96 \%$ \\
Not Held Not Target & $24 \%$ & $(0.6)$ & $31 \%$ & $(0.7)$ & $18 \%$ \\
Lib Dem & & & & & \\
Held Not Target & $*$ & $*$ & $*$ & $*$ & $30 \%$ \\
Target & $73 \%$ & $(2.0)$ & $90 \%$ & $(2.9)$ & $88 \%$ \\
Not Held Not Target & $22 \%$ & $(0.4)$ & $19 \%$ & $(0.3)$ & $21 \%$
\end{tabular}

Note: The percentages show the proportion of constituencies which received a leadership visit. For 1992 and 1997, figures in parenthesis represent the mean number of visits by party leadership figures

* Too few cases for analysis

Table 12. Mean Effort in Targeting Specific Groups

$\begin{array}{lrrrr} & \mathbf{1 9 9 2} & \mathbf{1 9 9 7} & \mathbf{2 0 0 1} & \mathbf{2 0 0 5} \\ \text { Conservative } & 2.8 & 2.6 & 2.6 & 3.0 \\ \text { Held Not Target } & 2.5 & 2.7 & 2.5 & 3.7 \\ \text { Target } & 3.4 & 3.3 & 3.1 & 2.7 \\ \text { Not Held Not Target } & 2.8 & 2.3 & 2.3 & 2.2 \\ & & & & \\ \text { Labour } & 3.0 & 2.9 & 2.8 & 2.8 \\ & & & & \\ \text { Held Not Target } & 3.0 & 3.0 & 2.8 & 3.6 \\ \text { Target } & 3.7 & 4.2 & 3.7 & 3.1 \\ \text { Not Held Not Target } & 2.6 & 2.5 & 2.3 & 2.0 \\ & & & & \\ \text { Lib Dems } & 2.1 & 2.1 & 2.0 & 2.4 \\ & & & & \\ \text { Held Not Target } & * & * & 3.0 & 3.6 \\ \text { Target } & 3.0 & 3.9 & 3.7 & 4.0 \\ \text { Not Held Not Target } & 2.0 & 2.0 & 1.8 & 2.0 \\ & & & & \\ \text { * Too few cases for analysis } & & \end{array}$


Table 13. Summarizing Stages of Development in British Constituency Campaigning

Stage Reached

\section{Conservative Labour Liberal \\ Democrats}

\begin{tabular}{llccc} 
Technical & Preparation & 2 & 2 & 2 \\
& Use of Technology & $2 / 3$ & $2 / 3$ & $2 / 3$ \\
Resource & Centralisation & 2 & 2 & 2 \\
& Staffing & $2 / 3$ & $3 / 2$ & $2 / 3$ \\
& Feedback & $3 / 2$ & $3 / 2$ & 2 \\
\multirow{5}{*}{ Thematic } & Party Leaders & $2 / 3$ & $3 / 2$ & $2 / 3$ \\
& Voter Targeting & 3 & 3 & 3
\end{tabular}




\section{Appendix}

The numbers of cases involved in Tables 1-12 are as follows:

Conservative

1992

Held non-target
Target
Not held not target
Total

Labour

Held non-target

Target

Not held not target

Total

Liberal Democrat

Held non-target

Target

Not held not target

Total

\section{6}

45

84

265

\section{8}

94

163

355

$-$

33

350

383
1997

166

64

204

434

168

65

222

455

1

29

381

411
2001

122

103

150

375

183

96

164

443

10

33

389

432
2005

39

23

6

68

162

51

121

334

23

24

165

212

\section{Variables Used to Create the Index of Long-Term Campaigning}

- Length of time the agent had been appointed (Just before the campaign, Within the last 6 months, Within the last year, More that a year ago)

- When the party started planning for the campaign (Just before the campaign, Within the last 6 months, Within the last year, More that a year ago)

- How prepared the party was in appointing people to do specific campaign jobs (5 point scale: $1=$ Not Started, 5 = Fully Prepared)

- How prepared the party was in raising campaign funds (5 point scale: $1=$ Not Started, $5=$ Fully Prepared)

- How prepared the party was in deciding the location of the main committee room (5 point scale: $1=$ Not Started, 5 = Fully Prepared)

- How prepared the party was in obtaining a copy of the electoral register $(5$ point scale: $1=$ Not Started, $5=$ Fully Prepared)

- How prepared the party was in preparing the content of the candidate's election address (5 point scale: $1=$ Not Started, 5 = Fully Prepared)

- How prepared the party was in making arrangements for printing campaign material (5 point scale: $1=$ Not Started, 5 = Fully Prepared)

- *How prepared the party was in identifying potential supporters through canvassing (5 point scale: $1=$ Not Started, 5 = Fully Prepared)

- *Telephone canvassing from within the constituency by telephone in the year before the election (No, A little, A substantial amount)

- *Use of long-term canvass records ( 5 point scale: $1=$ Not at All, $5=$ To a great extent)

* = Variable not available in 1992. 


\section{Variables Used to Create Index of Traditionalism}

- No. of posters distributed per elector (n)

- No. of leaflets delivered per elector (n)

- $\%$ of electorate canvassed on the doorstep $(\%)$

- No. of public meetings (n)

- Mean nos. of campaign and polling day workers (n)

- Level of 'manual' activity on polling day (including delivery of last-minute leaflets (Yes/No), 'knockingup' (Yes/No), proportion of the electorate covered by number-takers (\%))

\section{Variables Used to Create Index of Modernisation}

- $\quad *$ Use of computers (Yes/No)

- *Use of computerised electoral register (Yes/No)

- *Used party software (Yes/No)

- *Approximate use of telephone canvassing (\%)

- *Used computers for 'knocking-up' (Yes/No)

- $\quad * *$ Used telephones for 'knocking-up' (Yes/No)

- $\quad * *$ Use of direct mail (\%)

- $\quad * * \%$ electorate canvassed by telephone $(\%)$

* These variables are available for all four elections and were used to create modernisation index A.

** These variables are available for elections from 1997 and are used, together with the other variables, except the approximate use of telephone canvassing, to create modernisation index B.

\section{Variables Used to Create Index of Centralisation}

- *Amount of National contact before campaign (Hardly Ever, Occasionally, Once a Month, Once a Week)

- *Amount of Regional contact before campaign (Hardly Ever, Occasionally, Once a Month, Once a Week)

- *Amount of National contact during campaign (Hardly Ever, Once a Week, Every Day)

- *Amount of Regional contact during campaign (Hardly Ever, Once a Week, Every Day)

- $\quad$ *Whether used election software supplied by party headquarters (Yes/No)

- *Whether special organiser appointed from centre (Yes/No)

- **Length of time special organiser appointed before election (Just Before the Election, Within the Last 6 Months, Within the Last Year, Over a Year Ago)

- $\quad * *$ Whether there was telephone canvassing from outside constituency (Yes/No)

* These variables are available for all four elections and were used to create the centralisation index for 1992-2005.

** These variables are available for elections from 1997 and are used, together with the other variables, to create the centralisation index for 1997-2005

\section{Variables Used to Create the Index of Feedback}

- Pre-Election Telephone Canvassing within constituency (No, A little, A substantial amount)

- Direct Mail used to target individual voters (No, A little, A substantial amount)

- Used Telephone canvassing (No, A little, A substantial amount)

- Telephone canvassing organised from outside the constituency (Yes/No)

- Use of previous canvass records (5 point scale: $1=$ Not at All, $5=$ To a great extent)

- Campaign effort - telephone canvassing (5 point scale: 1 = Very Little or No Effort, 5 = Very Substantial Effort) 


\section{References}

Butler, D. and King, A. (1966) The British General Election of 1966, London: MacMillan.

Butler, D. and Kavanagh, D. (1974) The British General Election of February 1974, London: MacMillan.

Butler, D. and Kavanagh, D. (1975) The British General Election of October 1974, London: MacMillan.

Butler, D. and Kavanagh, D. (1980) The British General Election of 1979, London: MacMillan.

Carty, R.K., Eagles, D.M., and Sayers, A. (2003) 'Candidates and Local Campaigns. Are There Just Four Canadian Types?', Party Politics, 9 (5): 619-36.

Denemark, D. (2003) 'Electoral Change, Inertia and Campaigns in New Zealand. The First Modern FPP Campaign in 1987 and the First MMP Campaign in 1996', Party Politics, 9 (5): 601-18.

Denver, D. (2003) Elections and Voters in Britain, Basingstoke: Palgrave

Denver, D. and Hands, G. (1997) Modern Constituency Electioneering, London: Frank Cass.

Denver, D. and Hands, G. (2002) 'Post-Fordism in the constituencies?' in D. Farrell and R. Schmitt-Beck (eds) Do Political Campaigns Matter? London: Routledge, pp. 108-26.

Denver, D., Hands, G., Fisher, J. and MacAllister, I. (2002) 'The Impact of Constituency Campaigning in the 2001 General Election', British Elections and Parties Review 12: 8094.

Denver, D., Hands, G., Fisher, J. and MacAllister, I. (2003) 'Constituency Campaigning in Britain 1992-2001: Centralisation and Modernisation', Party Politics, 9 (5): 541-59

Farrell, D.M. and Webb, P. (2002) 'Political Parties as Campaign Organisations' in R. J. Dalton and M.P. Wattenburg (eds) Parties without Partisans, Oxford: OUP, pp.102-28.

Farrell, D.M. and Scully, R. (2007) Representing Europe's Citizens? Oxford: Oxford University Press.

Fisher, J. (2000) 'Small Kingdoms and Crumbling Organisations: Examining the Variation in Constituency Party Membership and Resources', British Elections and Parties Review Volume 10: 133-50.

Fisher, J. (2005) 'Campaign finance' in A. Geddes and J. Tonge (eds) Britain Decides: The UK General Election 2005 Basingstoke: Palgrave. 
Fisher, J., Denver, D., Fieldhouse, E., Russell, A. and Cutts, D. (2007) 'Constituency Campaigning in 2005: Ever More Centralisation?' in D. Wring and J. Green (eds) Political Communications: The British General Election of 2005 Basingstoke: Palgrave , pp.79-92.

Fisher, J., Fieldhouse, E., Denver, D., Russell, A. and Cutts, D. (2005) The General Election 2005: Campaign Analysis. Report Prepared for the Electoral Commission.

Fisher, J. Denver, D. and Hands, G. (2006a) 'The Relative Electoral Impact of Central Party Co-ordination and Size of Party Membership at Constituency Level', Electoral Studies, 25 (4): 664-76.

Fisher, J., Denver, D., and Hands, G., (2006b) 'Party Membership and Campaign Activity in Britain: The Impact of Electoral Performance', Party Politics, 12 (4): 505-19.

Fisher, J., Denver, D., and Hands, G., (2006c) 'Unsung Heroes: Constituency Election Agents in British General Elections' British Journal of Politics and International Relations, 8 (4):569-86.

Gerber, A.S., and Green, D.P. (2000) 'The Effects of Canvassing, Telephone Calls, and Direct Mail on Voter Turnout: A Field Experiment', American Political Science Review, 94: 653-63.

Gerber, A.S., and Green, D.P. (2001) 'Do Phone Calls Increase Voter Turnout?' Public Opinion Quarterly, 65: 75-85.

Hanham, H.J. (1978) Elections and Party Management, Sussex: The Harvester Press.

Marsh, M. (2004) 'None of that Post-modern stuff around Here: Grassroots Campaigning in the 2002 Irish General Election', British Elections and Parties Review, 14: 245-67.

Nicholas, H.G (1951) The British General Election of 1950, London: Macmillan.

Norris, P. (2002) 'Campaign Communications' in L. LeDuc, R.G. Niemi and P. Norris (eds) Comparing Democracies 2, London: Sage pp. 127-47.

Pattie, C. and Johnston, R. (2003) 'Hanging on the Telephone? Doorstep and Telephone Canvassing at the British General Election of 1997', British Journal of Political Science, 33: 303-22.

Scarrow, S. (2002) 'Parties Without Members? Party Organisation in a Changing Electoral Environment' in R. J. Dalton and M.P. Wattenburg (eds) Parties without Partisans, Oxford: OUP, pp.79-101.

Seyd, P. and Whiteley, P. (2002) New Labour's Grassroots (Basingstoke: Palgrave).

Ward, I. (2003) 'Localizing the National' The Rediscovery and Reshaping of Local Campaigning in Australia', Party Politics, 9 (5): 583-600. 
Webb, P. and Fisher, J. (2003) 'Professionalism and the Millbank Tendency: The political Sociology of New Labour's Employees' Politics, 23 (1): 10-20.

Whiteley, P. and Seyd, P. (2003) 'How to win a landslide by really trying: the effects of local campaigning on voting in the 1997 British general election', Electoral Studies, 22: 301-24. 